\title{
Serum complement components in patients with trachoma
}

\author{
D K SEN,' G S SARIN,' M HIRANANDANI,' AND U K BAVEJA \\ From 'Guru Nanak Eye Centre and the ${ }^{2}$ Department of Bacteriology, Maulana Azad Medical College, \\ New Delhi, India
}

SUMmary Serum C1q, C3, C4, and C5 components of complement levels were measured in 56 healthy subjects and 98 patients with trachoma. Serum $\mathrm{C1q}$ and $\mathrm{C} 3$ levels were found to be significantly low in stages II and III. There was no change in serum C4 and C5 levels in any of the stages. The levels of C1q and C3 complement components in serum in stages II and III returned to normal as the disease resolved following the medical treatment.

Trachoma is estimated to be responsible for $5 \%$ of visual impairment and blindness in India. ' Certain features of this disease have led to a suggestion that immunological responses may play some part in its pathogenesis. ${ }^{2}$ The complement system has a role in defending the host against infection. ${ }^{3}$ It has been established that activated complement is an important mediator of tissue inflammation. ${ }^{4}$ The ocular tissue is known to contain components for both classical and alternate pathway of activation of complement. ${ }^{5}$ However, very little work is available on serum complements in ocular diseases. In one report it has been found to be altered in acute adenovirus conjunctivitis. ${ }^{6}$ Here we report observations on the levels of complement components in serum in patients with different stages of trachoma and the effects of medical treatment.

\section{Material and methods}

The study was carried out on 56 healthy subjects and 98 patients with trachoma attending the outpatient department of Guru Nanak Eye Centre, New Delhi. The control group comprised healthy subjects who had no evidence of any ocular or systemic disease and who attended the Eye Centre during the same period mainly for the purpose of refraction. The patients with trachoma did not have any other ocular or systemic disease. The age and sex distribution of healthy subjects and the trachoma patients are given in Table 1.

Correspondence to Dr D K Sen, V/4 Maulana Azad Medical College Campus, Kotla Road, New Delhi 110 002, India.
The diagnosis of trachoma was established by detailed clinical examination with the help of a slitlamp biomicroscope and the stages were determined in accordance with MacCallan's classification' as modified by the World Health Organisation. ${ }^{8}$ The diagnosis of trachoma was further confirmed in the laboratory by Giemsa staining of inclusions in conjunctival scrapings. Only the Giemsa-positive cases were included in this study.

The serum samples were stored at $-20^{\circ} \mathrm{C}$ and assayed within three to four days of collection. They were analysed for $\mathrm{C} 1 \mathrm{q}, \mathrm{C} 3, \mathrm{C} 4$, and $\mathrm{C} 5$ complement components by a single radial immunodiffusion technique. ${ }^{9}$ Monospecific goat antisera against human C3, C4, and C5 complement components and their respective reference standards were obtained from Meloy Laboratories, Virginia, USA. Antihuman C1q complement component serum was obtained from Behring Institute, Frankfurt, West Germany. The levels of $\mathrm{Clq}$ complement component in the samples of sera were compared with WHO reference standard serum 67/97 and expressed in units/dl, the WHO reference standard being taken as 100 units/dl.

Patients with trachoma stages I, II, and III were treated by oral sulphonamides (sulphamethoxazole $30 \mathrm{mg}$ per kg of body weight daily in divided doses for adults and proportionately less for children according to body weight) for three weeks and topical therapy with tetracycline ointment $1 \%$ twice daily for 90 consecutive days. They were followed up once a week to ensure compliance with the treatment. On every visit a thorough clinical examination with the help of a slit-lamp biomicroscope was done. The treatment was considered to be effective when resolu- 
Table 1 Age and sex distribution of healthy subjects and patients with trachoma

\begin{tabular}{|c|c|c|c|c|c|c|c|c|}
\hline & \multirow[t]{2}{*}{$M$} & \multirow[t]{2}{*}{$F$} & \multirow[t]{2}{*}{ Total } & \multicolumn{5}{|c|}{ Age in years } \\
\hline & & & & $\begin{array}{l}20 \text { and } \\
\text { under }\end{array}$ & $21-30$ & $31-40$ & $41-50$ & $\begin{array}{l}51 \text { and } \\
\text { over }\end{array}$ \\
\hline Healthy subjects & 35 & 21 & 56 & 20 & 24 & 8 & 4 & - \\
\hline Trachoma patients & 51 & 47 & 98 & 34 & 23 & 18 & 17 & 6 \\
\hline Stage II & 13 & 11 & 24 & 14 & 7 & 3 & - & - \\
\hline Stage III & 15 & 10 & 25 & 3 & 6 & 7 & 7 & 2 \\
\hline Stage IV & 11 & 12 & 23 & - & 2 & 7 & 10 & 4 \\
\hline
\end{tabular}

tion of the disease was noted clinically and also Giemsa staining became negative for inclusions in conjunctival scrapings. Sixty-two patients fulfilled these criteria for effective medical treatment, and from them serum samples were again collected four months after the resolution of the disease as a result of medical treatment.

Stage IV being the remission stage of the disease required no medical treatment.

\section{Results}

Serum C1q, C3, C4, and C5 complement component levels in healthy subjects and patients with trachoma are given in Table 2 . The statistical analysis of the results was done by Student's $t$ test and $p<0.05$ was considered to be statistically significant. It was observed that the levels of serum $\mathrm{Clq}$ and $\mathrm{C} 3$ complement components were significantly lower than those in healthy subjects $(\mathrm{p}<0.05$ and $\mathrm{p}<0.01$ respectively). However, there was no statistically significant difference in the levels of serum $\mathrm{C} 4$ and $\mathrm{C5}$ complement components.

Table 2 also shows the levels of $\mathrm{C} 1 \mathrm{q}, \mathrm{C} 3, \mathrm{C} 4$, and
C5 complement components in stages I, II, III, and IV of trachoma. The serum C1q complement component level was significantly lower in stage II $(\mathrm{p}<0.05)$ and stage III $(\mathrm{p}<0.02)$ than were the respective levels in healthy subjects. The serum $\mathrm{C} 3$ complement component level was also lower in stage II $(\mathrm{p}<0.02)$ and stage III $(\mathrm{p}<0.01)$. However, the levels of serum $\mathrm{C} 4$ and $\mathrm{C} 5$ complement components were the same in all stages as in healthy subjects.

Table 3 shows the serum $\mathrm{C} 1 \mathrm{q}, \mathrm{C} 3$, and $\mathrm{C} 4$, and $\mathrm{C} 5$ complement component levels in patients with trachoma after the resolution of the disease following medical treatment. There was a significant rise in serum C1q complement component level $(p<0.001)$ and $\mathrm{C} 3$ complement component level $(\mathrm{p}<0.001)$ in treated patients (stages $\mathrm{I}+\mathrm{II}+\mathrm{III}$ ), and the levels almost attained those found in the healthy subjects. However, there was no significant alteration in the serum C4 and C5 complement component levels in these stages. Of the different stages of trachoma, only in stages II and III was there a significant rise in C1q level $(p<0.001$ and $p<0.01$ respectively) and C3 level $(p<0.01$ and $p<0.02$ respectively); the changes in the level of serum complement components C1q,

Table 2 Serum complement components (C3, C4, and C5) levels $\mathrm{mg} / \mathrm{dl}$ and Clq in units/dl in patients with different stages of trachoma and their correlation with the levels in healthy subjects

\begin{tabular}{|c|c|c|c|c|c|}
\hline & $\begin{array}{l}\text { No. of } \\
\text { cases }\end{array}$ & $\begin{array}{l}\text { Clq } \\
\text { Mean } \pm S D\end{array}$ & $\begin{array}{l}C 3 \\
M e a n \pm S D\end{array}$ & $\begin{array}{l}C 4 \\
\text { Mean } \pm S D\end{array}$ & $\begin{array}{l}C 5 \\
\text { Mean } \pm S D\end{array}$ \\
\hline Healthy subjects & 56 & $129 \cdot 2 \pm 36 \cdot 4$ & $169 \cdot 2 \pm 47 \cdot 5$ & $34 \cdot 4 \pm 17 \cdot 0$ & $11 \cdot 8 \pm 6 \cdot 5$ \\
\hline $\begin{array}{l}\text { Trachoma patients } \\
\text { (all stages) }\end{array}$ & 98 & $\begin{array}{l}116.8 \pm 29.5 \\
(p<0 \cdot 05)\end{array}$ & $\begin{array}{l}148 \cdot 8 \pm 32 \cdot 1 \\
(p<0 \cdot 01)\end{array}$ & $\begin{array}{l}31 \cdot 0 \pm 14 \cdot 0 \\
(\mathrm{NS})\end{array}$ & $\begin{array}{l}10 \cdot 6 \pm 6 \cdot 1 \\
\text { (NS) }\end{array}$ \\
\hline Stage I & 26 & $\begin{array}{l}121 \cdot 6 \pm 34 \cdot 3 \\
\text { (NS) }\end{array}$ & $\begin{array}{l}157 \cdot 4 \pm 32 \cdot 0 \\
\text { (NS) }\end{array}$ & $\begin{array}{l}32 \cdot 0 \pm 15 \cdot 7 \\
\text { (NS) }\end{array}$ & $\begin{array}{l}11 \cdot 2 \pm 6 \cdot 1 \\
\text { (NS) }\end{array}$ \\
\hline Stage II & 24 & $\begin{array}{l}113 \cdot 2 \pm 21 \cdot 1 \\
(p<0 \cdot 05)\end{array}$ & $\begin{array}{l}141 \cdot 8 \pm 29 \cdot 3 \\
(p<0 \cdot 02)\end{array}$ & $\begin{array}{l}30 \cdot 8 \pm 13 \cdot 6 \\
\text { (NS) }\end{array}$ & $\begin{array}{l}10 \cdot 1 \pm 5 \cdot 7 \\
\text { (NS) }\end{array}$ \\
\hline Stage III & 25 & $\begin{array}{l}108 \cdot 5 \pm 25 \cdot 5 \\
(p<0 \cdot 02)\end{array}$ & $\begin{array}{l}135 \cdot 8 \pm 31 \cdot 7 \\
(p<0 \cdot 01)\end{array}$ & $\begin{array}{l}29 \cdot 5 \pm 14 \cdot 1 \\
(N S)\end{array}$ & $\begin{array}{l}9 \cdot 9 \pm 6 \cdot 4 \\
\text { (NS) }\end{array}$ \\
\hline Stage IV & 23 & $\begin{array}{l}123 \cdot 1 \pm 34 \cdot 1 \\
\text { (NS) }\end{array}$ & $\begin{array}{l}161 \cdot 4 \pm 29 \cdot 5 \\
\text { (NS) }\end{array}$ & $\begin{array}{l}31 \cdot 6 \pm 12 \cdot 9 \\
(\mathrm{NS})\end{array}$ & $\begin{array}{l}11 \cdot 3 \pm 6 \cdot 5 \\
\text { (NS) }\end{array}$ \\
\hline
\end{tabular}

NS= not significant statistically. 
Table 3 Serum complement components (C3, C4, and C5) in mg/dl and C1q in units/dl in stage I, II, and III of trachoma after treatment and their correlation with pretreatment levels

\begin{tabular}{|c|c|c|c|c|c|}
\hline Stages & $\begin{array}{l}\text { No. of } \\
\text { cases }\end{array}$ & $\begin{array}{l}C l q \\
\text { Mean } \pm S D\end{array}$ & $\begin{array}{l}C 3 \\
\text { Mean } \pm S D\end{array}$ & $\begin{array}{l}C 4 \\
M e a n \pm S D\end{array}$ & $\begin{array}{l}\text { C5 } \\
\text { Mean } \pm S D\end{array}$ \\
\hline $\begin{array}{l}\text { Stages } I+I I+I I I \\
\text { Pretreatment } \\
\text { Post-treatment } \\
\text { p Value }\end{array}$ & $\begin{array}{l}75 \\
62\end{array}$ & $\begin{array}{l}114.9 \pm 27.9 \\
130.8 \pm 25 \cdot 1 \\
(p<0.001)\end{array}$ & $\begin{array}{l}145 \cdot 2 \pm 32 \cdot 2 \\
162 \cdot 2 \pm 25 \cdot 6 \\
(p<0 \cdot 001)\end{array}$ & $\begin{array}{l}30 \cdot 8 \pm 14.4 \\
32 \cdot 9 \pm 13 \cdot 9 \\
\text { (NS) }\end{array}$ & $\begin{array}{l}10 \cdot 4 \pm 6 \cdot 0 \\
11 \cdot 4 \pm 5 \cdot 8 \\
(\mathrm{NS})\end{array}$ \\
\hline $\begin{array}{l}\text { Stage I } \\
\text { Pretreatment } \\
\text { Post-treatment } \\
\text { p Value }\end{array}$ & $\begin{array}{l}26 \\
22\end{array}$ & $\begin{array}{l}121 \cdot 6 \pm 34 \cdot 3 \\
124 \cdot 8 \pm 27 \cdot 4 \\
\text { (NS) }\end{array}$ & $\begin{array}{l}157 \cdot 4 \pm 32 \cdot 0 \\
162 \cdot 0 \pm 28 \cdot 4 \\
\text { (NS) }\end{array}$ & $\begin{array}{l}32 \cdot 0 \pm 15 \cdot 7 \\
32 \cdot 9 \pm 13 \cdot 9 \\
\text { (NS) }\end{array}$ & $\begin{array}{l}11 \cdot 2 \pm 6 \cdot 1 \\
11 \cdot 5 \pm 5 \cdot 8 \\
\text { (NS) }\end{array}$ \\
\hline $\begin{array}{l}\text { Stage II } \\
\text { Pretreatment } \\
\text { Post-treatment } \\
\text { p Value }\end{array}$ & $\begin{array}{l}24 \\
20\end{array}$ & $\begin{array}{l}113 \cdot 2 \pm 21 \cdot 1 \\
137 \cdot 0 \pm 21 \cdot 9 \\
(p<0 \cdot 001)\end{array}$ & $\begin{array}{l}141 \cdot 8 \pm 29 \cdot 3 \\
165 \cdot 8 \pm 23 \cdot 0 \\
(p<0 \cdot 01)\end{array}$ & $\begin{array}{l}30 \cdot 8 \pm 13 \cdot 6 \\
33 \cdot 7 \pm 12 \cdot 9 \\
\text { (NS) }\end{array}$ & $\begin{array}{l}10 \cdot 1 \pm 5 \cdot 7 \\
11 \cdot 7 \pm 6 \cdot 3 \\
\text { (NS) }\end{array}$ \\
\hline $\begin{array}{l}\text { Stage III } \\
\text { Pretreatment } \\
\text { Post-treatment } \\
\text { p Value }\end{array}$ & $\begin{array}{l}25 \\
20\end{array}$ & $\begin{array}{l}108.5 \pm 25.5 \\
130.9 \pm 26.0 \\
(p<0.01)\end{array}$ & $\begin{array}{l}135.8 \pm 31.7 \\
158.9 \pm 25.7 \\
(p<0.02)\end{array}$ & $\begin{array}{l}29 \cdot 5 \pm 14 \cdot 1 \\
32 \cdot 2 \pm 12 \cdot 1 \\
\text { (NS) }\end{array}$ & $\begin{array}{l}9 \cdot 9 \pm 6 \cdot 4 \\
10 \cdot 9 \pm 5 \cdot 5 \\
\text { (NS) }\end{array}$ \\
\hline
\end{tabular}

No medical treatment was given in stage IV because this was the remission stage of the disease.

C3, C4 and C5 in stage I, and C4 and C5 in stages II and III were not statistically significant.

\section{Discussion}

The presence of a multiple-system mediating host defence makes the evaluation of the specific role of any single system difficult. This has been particularly true in assessing the role of complement in ocular diseases. In spite of such difficulties it is apparent that complement does have a specific role in the host's defence in man. ${ }^{10}$ The complement system in human serum is able to neutralise or enhance neutralisation of certain viruses in vitro by mechanisms involving both the classical and alternate pathway. ${ }^{11}$ Diseases associated with altered serum complement levels in man have been observed during hepatitis type $B$, Epstein-Barr virus infection, Argentine haemorrhagic fever, and subacute sclerosing panencephalitis. ${ }^{13}$ It has been shown in corneal inflammation that activation of complements by either the classic or the alternate pathway may be involved. ${ }^{14} 15$

$\mathrm{C} 1 \mathrm{q}, \mathrm{C} 3$, and $\mathrm{C} 4$ components of complement represent acute-phase reactant in human serum. ${ }^{16} \mathrm{C} 3$ component of complement is common to both the classical and the alternate pathways of activation and is biologically important in that its activation products mediate many of the features of the inflammatory response. ${ }^{17}$ The serum concentration of $\mathrm{C} 3$ complement component is therefore expected to be affected by accelerated catabolism as a result of complement activation. A low serum concentration of $\mathbf{C} 3 \mathrm{com}-$ ponent in serum has been reported in patients with acute adenovirus conjunctivitis, ${ }^{6}$ acute viral lower respiratory tract illness, ${ }^{18}$ Argentine haemorrhagic fever, ${ }^{19}$ and acute type B hepatitis. ${ }^{20}$ In the present study significantly low levels of $\mathrm{C} 3$ complement in serum have been observed in patients with stages II and III of trachoma. Viral lysis initiation is reported to be carried out by C1q component of complement. ${ }^{10}$ A significant depression of serum C1q component of complement level in patients with stages II and III of trachoma has been observed in the present study. Clq complement component in serum has also been reported to be low in acute adenovirus conjunctivitis ${ }^{6}$ and Junin virus haemorrhagic fever. ${ }^{19}$ Low levels of $\mathrm{C} 1 \mathrm{q}$ and $\mathrm{C} 3$ complement components in serum may be due to the activation of the classical and/or alternate pathway, transient depression of complement component synthesis, increased catabolism, or the presence of inhibitors of complement action.

There was no significant alteration in the levels of $\mathrm{C} 4$ and $\mathrm{C} 5$ complement components in serum in any of the stages of trachoma. In acute adenovirus conjunctivitis also no significant alterations in $\mathrm{C} 4$ and C5 levels in serum have been reported. ${ }^{6}$

$\mathrm{C} 1 \mathrm{q}, \mathrm{C} 3$, and $\mathrm{C} 4$ components of complement in serum were normal or increased during the acute phase and normal in the convalescent phase in patients with Epstein-Barr virus infection. ${ }^{21}$ It has been suggested that complement is important to the patients recovery from viral respiratory tract infection. ${ }^{22}$ The observation that the low levels of $\mathrm{C} 1 \mathrm{q}$ and C3 complement components became normal when the disease resolved spontaneously, as in stage IV, or after treatment, as in stage II and III, is therefore interesting. 


\section{References}

1 Park JE, Park K. Text book of preventive and social medicine. 9th ed. Banarsi Dass Bhanot, India: 1983: 383-5.

2 Silverstein AM, Prendergast RA. Lymphofollicular hyperplastic responses in ectopic locations: trachoma as paradigm. In: Lindahl Kiessling K, Alm G, Hanna MG, eds. Morphological and functional aspects of immunity. New York: Plenum Press, 1971.

3 Ruddy S, Gigli I, Austen KF. Complement systems of man. N Engl J Med 1972; 287: 489-92.

4 Roitt I. Essential immunology. Oxford: Blackwell, 1977: 141-7.

5 Mondino BJ, Tatajezak HV, Goldberg DB, Scharizlen DJ, Brown SI. Alternate and classical pathway components in the normal cornea. Arch Ophthalmol 1980; 98: 346-9.

6 Gupta AK, Sarin GS. Serum complement component depression during acute adenovirus conjunctivitis. Br J Ophthalmol 1984; 68: $350-2$.

7 MacCallan AF. Trachoma and its complications in Egypt. London: Cambridge University Press, 1913: 5.

8 WHO Expert Committee on Trachoma. Third report 1962. WHO Tech Rep Ser 1962; 234: 15.

9 Mancini G, Carbonara AO, Heremans JF. Immunochemical quantitation of antigens by radial immunodiffusion. Int J Immunochem 1965; 2: 235-54.

10 Agnello V. Complement deficiency states. Medicine (Baltimore) 1978; 57: 1-23.

11 Cooper NR, Jensen FC, Welsh RM Jr, Oldstone MBA. Lysis of RNA tumor viruses by human serum: direct antibody-independent triggering of the classical complement pathway. J Exp Med 1976; 144: 970-84.

12 Daniels CA, Borsos T, Rapp HJ, Snyderman R, Notkins AL.
Neutralization of sensitized virus by the fourth component of complement. Science 1969; 165; 508-9.

13 Oldstone MBA. Virus neutralization and virus induced immune complex disease. Virus-antibody union resulting in immunoprotection or immunologic injury-two sides of the same coin. Prog Med Virol 1975; 19: 84-119.

14 Mondino BJ, Rabin BS, Kessler E. Corneal rings with Gram negative bacteria. Arch Ophthalmol 1977; 95: 2222-5.

15 Mondino BJ, Brown SI, Rabin BS, Bruno BJ. Alternate pathway activation of complement in Proteus mirabilis ulceration of cornea. Arch Ophthalmol 1978; 96: 1659-61.

16 Hornung $M$, Arquembourg RC. $\beta 1 C$ globulin: an acute phase reactant of human serum. J Immunol 1965; 94: 307-16.

17 Fearon DT, Austen KF. The human complement system. Biochemistry, biology and pathology. Essays Med Biochem 1976; 2: 1-22.

18 Strunk RC, Sieber OF, Taussig LM, Gall EP. Serum complement depression during viral lower respiratory tract illness in cystic fibrosis. Arch Dis Child 1977; 52: 687-90.

19 de Bracco MME, Carballal G, Arana RM. Argentine hemorrhagic fever: alteration of the complement system and anti-Junin virus humoral response. $N$ Engl J Med 1978; 299: 216-21.

20 Thomas HC, deVilliers D, Potter BJ, et al. Immune complexes in acute and chronic liver disease. Clin Exp Immunol 1978; 31: $150-7$.

21 Boughton CR. Complement, lymphotoxins and immune complexes in infectious mononucleosis: serial studies in uncomplicated cases. Clin Exp Immunol 1978; 34: 241-7.

22 Hicks JT, Ennis FA, Kim E, Verbonitz M. The importance of an intact complement pathway in recovery from a primary viral infection: influenza in decompensated and in $\mathrm{C} 5$ deficient mice. $J$ Immunol 1978; 121: 1437-45. 